\title{
DEKLOROFILASI EKSTRAK PROTEASE DARI TANAMAN BIDURI (Calotropis gigantea) DENGAN ABSORBAN CELITE
}

\author{
Yuli Witono \\ Fakultas Teknologi Pertanian Universitas Jember \\ Koresponden Penulis Pertama: FTP-UNEJ; JI. Kalimantan I-Kampus Tegal Boto, Jember \\ Kode Pos: 68121, HP: 081336700946; email: ylwitono@yahoo.com
}

\begin{abstract}
'Biduri' plant is a wild bush in tropical countries which is one of potential protease source. However, protease extracted from leaf and stamp top of biduri is still green in color due to contain a protein bounding-chlorophyll. It would be problem if it is used for some food. The objective of this rearch was to study a dechloroplyllation technique in order to obtain protease with low chlorophyll content but high specific activity. The results showed that the best dechlorophyllation method of biduri protease could be eluted by celite absorbance. The first step elution was obtained $16 \mathrm{ml}$ filtrate of biduri protease with low chlorophyll. Consist to the result above also decreased protein content, with loading capacity was 1.067 gram biduri/gram celite or $0.015 \mu \mathrm{g}$ chlorophyll/gram celite. However in the second step elution, after biduri filtrate has been freezed for 12 hours was obtained the dechlorophylated biduri protease was higher in loading volume. Resulting in increased of loading capacity to be 2.13 gram biduri/gram celite or $0.004 \mu \mathrm{g}$ chlorophyll/gram celite. The chlorophyll decreased to about $<44 \%$ of chlorophyll from the first step elution, even the specific activity increased $286 \%$ compared with the first step elution.
\end{abstract}

Key words: dechlorophyllation, celite absorbance, protease, biduri plant

\section{PENGANTAR}

Ketersediaan enzim protease belum mencukupi kebutuhan, sementara pemakaian protease bagi industri pangan cenderung meningkat. Pada tahun 1983 penjualan enzim protease mencapai $40 \%$ dari total penjualan enzim dunia (Word, 1983), tahun 1995 meningkat sampai 60\% dari total pemakaian enzim dunia (Suhartono dkk., 1995). Bahkan pada tahun 1998 mencapai $70 \%$ dari total pemakaian enzim untuk pangan (Rao et al., 1998).

Enzim protease bersumber dari organisme hidup yang meliputi: mikroba, hewan maupun tanaman antara lain getah pepaya, melon, daun chaya, dan biji padi. Namun demikian untuk memproduksi enzim protease dari beberapa sumber tersebut masih menghadapi banyak kendala. Meskipun mikroba dikenal luas sebagai sumber enzim protease, namun untuk tujuan-tujuan tertentu, misalnya pengempuk daging, enzim protease dari tanaman masih mempunyai peranan yang sangat besar yang belum sepenuhnya dapat digantikan oleh enzim mikroba. Enzim yang diproduksi dari jaringan hewan relatif mahal dan ketersediaannya tergantung pada permintaan hewan-hewan sumber enzim tersebut di pasaran, mengingat enzim harus diekstrak dari hewan-hewan yang sudah mati. Sedangkan enzim protease yang diproduksi dari tanaman seperti papain dari getah pepaya, akan mengakibatkan penurunan kualitas pada buah segarnya setelah disadap.
Oleh karena itu, perlu dicari sumber-sumber enzim protease yang lain. Salah satunya adalah biduri (Calotropis gigantea) yang merupakan jenis tumbuhan semak liar di daerah tropis termasuk Indonesia. Menurut Van Stenis (1992) tumbuhan ini banyak tumbuh pada lahan kering dan sampai saat ini belum banyak dimanfaatkan, bahkan pada beberapa daerah dianggap sebagai gulma.

Getah tanaman biduri dapat digunakan sebagai sumber enzim protease (Witono, 2002a; Witono, 2002b). Telah berhasil dikembangkan teknik produksi protease yang diekstrak secara langsung dari tanaman biduri, yakni dari daun dan pucuk batang biduri (Witono dkk., 2006). Teknik ini diketahui jauh lebih mudah dibanding ekstraksi dari getah, juga tidak terlalu berisiko terhadap penurunan aktivitas enzimnya selama produksi. Akan tetapi hasil dari teknik ini berupa crude protease yang berwarna hijau karena masih terkontaminasi dengan pigmen klorofil yang terikat pada protein enzim sehingga akan bermasalah apabila diaplikasikan pada jenis produk pangan tertentu. Maka perlu dikembangkan teknik deklorofilasi dalam produksi protease yang diekstrak secara langsung dari tanaman biduri. Penelitian ini bertujuan untuk menelaah teknik deklorofilasi agar didapat crude protease dengan minimal atau bebas klorofil yang memiliki aktivitas spesifik tinggi. 


\section{BAHAN DAN CARA KERJA}

\section{Bahan dan Alat}

Bahan baku yang digunakan dalam penelitian ini adalah batang dan daun tumbuhan biduri (Calotropis gigantea) yang didapat dari Pantai Watu Ulo, Kecamatan Ambulu, Kabupaten Jember. Daun beserta batang biduri yang telah dipotong dari induknya langsung dimasukkan dalam wadah tertutup yang telah berisi es batu. Bahan kimia yang digunakan berspesifikasi pure analysis sebagian besar dari Merck (Jerman) di antaranya ialah celite absorbance.

Sedangkan peralatan yang digunakan meliputi: sentrifuga Medifriger, sentrifuga Yenaco model YC-1180 (Jepang), Spectronic 21D Melton Roy, Spectrometer Geaesys 10 UV Scanning, Refrigerator, Freeze drier (Snijders Scientific), pH meter Jen Way tipe 3320 (Jerman), pengaduk magnetik Stuart Scientific, vorteks thermolyne type 16700 Mixer, lemari pendingin Ger ${ }^{\circledR}$, penangas air GFL 1083, kolom kromatografi, neraca analitik Ohaus dan pemanas listrik Gerhardt.

\section{Cara Kerja}

Penelitian dilakukan secara bertahap yang meliputi: Tahap I: penelitian pendahuluan; yakni mencari dechlorophylation agent yang paling sesuai dalam menurunkan kadar klorofil crude protease biduri. Tahap II: mengetahui profil elusi dari dechloropylation agent terpilih dan menentukan titik elusi sampai didapat protease biduri dengan kandungan klorofil minimal yang memiliki aktivitas spesifik protease tinggi. Tahap III: mengembangkan teknik deklorofilasi melalui pretreatment preparat pada suhu rendah. Analisis data dilakukan secara deskriptif (Suryabrata, 1994), ditabulasi dan diploting dalam bentuk grafik dan histogram.

\section{Penelitian pendahuluan}

Deklorofilasi dilakukan melalui kolom kromatografi menggunakan gel filtrasi CM Sephadex C-50, arang aktif dan celite absorbance. Filtrat dari ekstrak tumbuhan biduri dielusikan dalam kolom-kolom tersebut dalam jumlah terbatas, lalu diamati warna eluen dan aktivitas enzimnya. Selanjutnya dicuci kembali dechlorophylation agentnya untuk ditelaah kemungkinan dapat dipakai kembali. Kemudian ditentukan dechlorophylation agent yang paling sesuai yang dapat menghasilkan eluen protease biduri yang jernih, memiliki aktivitas enzim, lebih mudah dicuci dan dapat dipakai ulang.

\section{Penentuan profil elusi sampel melalui celite absorbance dan titik elusinya (Deklorofilasi Tahap 1)}

Filtrat dari tumbuhan biduri dielusikan dalam kolom kromatografi yang berisi 5 gram celite (sebagaimana dipilih dari hasil penelitian pendahuluan). Eluen ditampung setiap $2 \mathrm{ml}$ pada tabung reaksi. Elusi dihentikan sampai didapat eluen yang berwarna kehijauan. Sesuai hasil penelitian pendahuluan, elusi dihentikan sampai fraksi tabung $2 \mathrm{ml}$ ke-15. Setiap fraksi diamati kadar klorofil, kadar protein dan aktivitas enzimnya. Selanjutnya ditentukan titik elusi dan kapasitas loading sehingga didapat eluen dengan minimal klorofil dan minimal protein tetapi memiliki aktivitas enzim yang tinggi.

\section{Deklorofilasi melalui pretreatment preparat pada suhu rendah (freezing) (Deklorofilasi Tahap 2)}

Sebelum dielusi pada kolom kromatografi yang berisi celite, preparat dibekukan terlebih dahulu selama semalam ( $\pm 12 \mathrm{jam}$ ), kemudian dilelehkan dan disentrifuga pada suhu dingin. Supernatan dielusikan pada kolom kromatografi yang berisi 5 gram absorban celite sampai didapat eluen yang berwarna kehijauan. Eluen ditampung setiap $4 \mathrm{ml}$ pada tabung reaksi dan elusi dihentikan sampai tabung kesepuluh (didapat $40 \mathrm{ml}$ eluen). Selanjutnya dipelajari profil elusinya, dengan mengamati perubahan kadar klorofil, kadar protein dan aktivitas enzimnya, serta dihitung kapasitas loading setiap kolom.

\section{Pembandingan profil elusi preparat pasca-Freezing dengan preparat pra-freezing}

Mengekstrak 100 gram tumbuhan biduri dengan $300 \mathrm{ml}$ buffer phosphat $0,05 \mathrm{pH} 7$ yang mengandung $0,07 \%$ natrium metabilsulfit, lalu disentrifus. Selanjutnya preparat dari supernatan biduri dijadikan 2 bagian. Preparat bagian pertama langsung dielusikan ke dalam kolom kromatografi yang berisi 5 gram celite sampai diperoleh 16 eluen terdeklorofilasi, lalu diamati kadar klorofil, kadar protein dan aktivitas enzimnya. Preparat bagian kedua di freezing semalam ( $\pm 12 \mathrm{jam}$ ) lalu di thawing pada suhu $4^{\circ} \mathrm{C}$. Selanjutnya dielusi ke dalam kolom kromatografi yang berisi 5 gram celite sampai diperoleh $32 \mathrm{ml}$ eluen terdeklorofilasi, diamati kadar klorofil, kadar protein dan aktivitas enzimnya. Profil kedua eluen diploting dalam histogram dan dibandingkan secara deskriptif. 


\section{Analisis Kadar Klorofil}

Analisis kadar klorofil dilakukan menurut metode Gilpin (2001). Sebanyak 0,5 ml eluen ditampung dalam tabung sentrifuga, ditera sampai volumenya menjadi $5 \mathrm{ml}$ lalu diaduk. Diamati absorbannya melalui spektrofotometer pada panjang gelombang 665 dan $750 \mathrm{~nm}$. Selanjutnya eluen diasidifikasi dengan menambahkan 4 tetes $\mathrm{HCl} 1 \mathrm{M}$, lalu diaduk dan disentrifuga. Supernatan yang diperoleh diamati kembali absorbannya pada panjang gelombang 665 dan $750 \mathrm{~nm}$. Adapun rumus perhitungan kadar klorofil dalam ekstrak adalah sebagai berikut:

Kadar klorofil $\left(\mu \mathrm{g} \cdot \mathrm{ml}^{-1}\right)=\frac{26.7 \times\left(665_{\mathrm{b}}-665_{\mathrm{a}}\right)}{\mathrm{L}}$

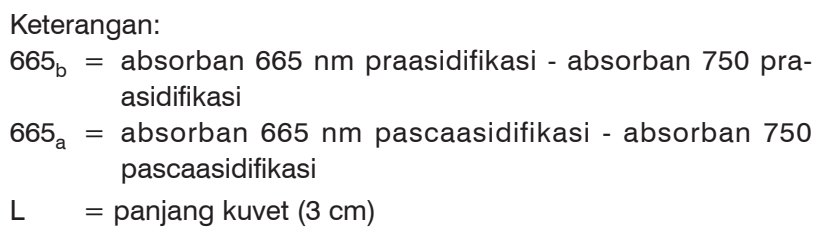

\section{Analisis Kadar Protein}

Analisis kadar protein dilakukan menurut metode Lowry dalam Walker (2002). Mengambil sampel eluen sebanyak $0,125 \mathrm{ml}$ untuk masing-masing fraksi, lalu dilakukan hidrolisis protein untuk mendapatkan protein terlarut dengan menggunakan $0,1 \mathrm{ml} \mathrm{NaOH} 2 \mathrm{~N}$ dan dipanaskan pada suhu $100^{\circ} \mathrm{C}$ selama 10 menit lalu didinginkan. Direaksikan dengan 2,5 $\mathrm{ml}$ reagen mix-lowry dan didiamkan selama 10 menit. Ditambahkan $0,25 \mathrm{ml}$ reagen follin dan dibiarkan selama 30 menit. Ditera dengan aquades sampai volume $5 \mathrm{ml}$ kemudian dibaca absorbannya dengan spektrofotometer pada panjang gelombang $750 \mathrm{~nm}$. Data absorbansi diplotkan pada kurva standar untuk dihitung kadar proteinnya.

\section{Pengujian Aktivitas Protease}

Pengujian aktivitas protease dilakukan menurut Stoknes dan Rustad (1995) dan Walker (2002). Menimbang 0,01 gram soluble casein dalam tabung sentrifus lalu dicampur dengan $3 \mathrm{ml}$ buffer phospat $\mathrm{pH}$ 7. Kemudian dilakukan pra inkubasi pada suhu $37^{\circ} \mathrm{C}$ selama 4 menit. Menambahkan sampel eluen protease biduri sebesar $0,5 \mathrm{ml}$, kemudian dilakukan inkubasi pada suhu $55^{\circ} \mathrm{C}$ selama 10 menit. Pada akhir inkubasi reaksi hidrolisis dihentikan dengan menambahkan $1 \mathrm{ml}$ larutan TCA 15\%. Sebagai kontrol (tanpa inkubasi), reaksi hidrolisis dilakukan pada waktu 0 menit, yakni penambahan $1 \mathrm{ml}$ larutan TCA $15 \%$ dilakukan sebelum penambahan protease. Lalu ditera sampai volumenya menjadi $5 \mathrm{ml}$, disentrifugasi pada kecepatan 1000 rpm selama 10 menit. Supernatan diamati absorbannya pada spektrofotometer UV dengan panjang gelombang $280 \mathrm{~nm}$. Data absorbansi diplotkan pada kurva standar tirosin untuk dihitung aktivitas hidrolisisnya.

Aktivitas protease dinyatakan dalam unit aktivitas, satu unit berarti peningkatan konsentrasi protein terlarut sejumlah satu $\mu$ mol pada setiap menit waktu inkubasi. Aktivitas spesifik enzim dinyatakan dalam unit aktivitas per miligram protein enzim. Perhitungan aktivitas spesifik enzim dapat menggunakan rumus sebagai berikut:

$$
1 \text { unit aktivitas }=\frac{[\mathrm{C}]}{\mathrm{t}} \times \frac{1000}{181.19}
$$

\section{Keterangan}

[C] $=$ konsentrasi protein terlarut $(\mu \mathrm{mol}$ tirosin $/ \mathrm{ml})$

$\mathrm{t} \quad=$ waktu hidrolisis (menit)

$181.19=$ berat molekul tirosin

1 unit $=1 \mu \mathrm{mol}$ tirosin yang dibebaskan dari substrat oleh setiap $\mathrm{mg}$ enzim pada suhu $55^{\circ} \mathrm{C}$ per menit.

\section{Volume Loading dan Kapasitas Loading}

Volume loading merupakan jumlah filtrat biduri yang yang terdeklorofilasi setiap gram dechlorophylation agent dapat dihitung dengan rumus sebagai berikut:

$$
\text { Volume loading }=\frac{\text { Volume Ekstrak terdeklorofilasi }(\mathrm{ml})}{\text { Berat Dechlorophylation Agent }(\mathrm{g})}
$$

Kapasitas loading adalah kemampuan setiap dechlorophylation agent dalam menurunkan kadar klorofil dihitung dengan rumus sebagai berikut:

$$
\text { Kapasitas loading }=\frac{\left[\text { Chlor }^{\mathrm{A}}\right]-\left[\text { Chlor }^{\mathrm{B}}\right] / \mathrm{V}}{\mathrm{W}}
$$

Keterangan:

$\left[\right.$ Chlor $\left.^{\mathrm{A}}\right]=$ Kadar klorofil filtrat awal $\left(\mu \mathrm{g} \cdot \mathrm{ml}^{-1}\right)$

$\left[\right.$ Chlor $\left.^{B}\right]=$ Kadar klorofil filtrat terdeklorofilasi $\left(\mu \mathrm{g} \cdot \mathrm{ml}^{-1}\right)$

$\mathrm{V} \quad=$ Total volume filtrat terdeklorofilasi $(\mathrm{ml})$

$\mathrm{W} \quad=$ Berat dechlorophylation agent (g)

\section{HASIL}

\section{Penelitian Pendahuluan}

Gel filtrasi CM Sephadex C-50, arang aktif maupun absorban celite memiliki kemampuan menurunkan kadar klorofil filtrat tanaman biduri, sebagaimana ditunjukkan dengan dihasilkannya warna yang lebih jernih pada fraksifraksi eluen awal. Akan tetapi CM Sephadex C-50 relatif lebih mahal dibanding celite, juga nilai reuse-nya menurun untuk deklorofilasi crude protease biduri karena pencucian 
jauh lebih sulit dibanding celite. Sedang eluen dari arang aktif masih mengandung sedikit butir-butir arang yang mengambang dalam eluen. Untuk itu selanjutnya dipilih deklorofilasi menggunakan celite absorbance, karena disamping harganya jauh lebih murah, juga preparasi dan pencuciannya lebih muda. Bahkan setelah dipakai ulang, kapasitas loading-nya tidak menurun. Adapun proses deklorofilasi melalui kolom celite absorbance sebagaimana tertera pada Gambar 1.

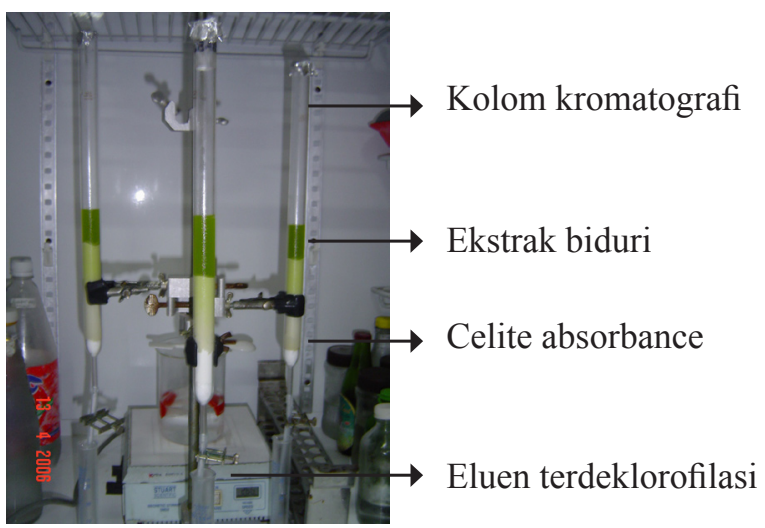

Gambar 1. Foto proses deklorofilasi ekstrak protease tanaman biduri

\section{Profil Elusi Protease Tanaman Biduri Terdeklorofilasi Pada Celite Absorbance}

Profil elusi protease dari ekstrak tanaman biduri yang terdeklorofilasi pada celite absorbance tertera pada Gambar 2 dan Gambar 3.

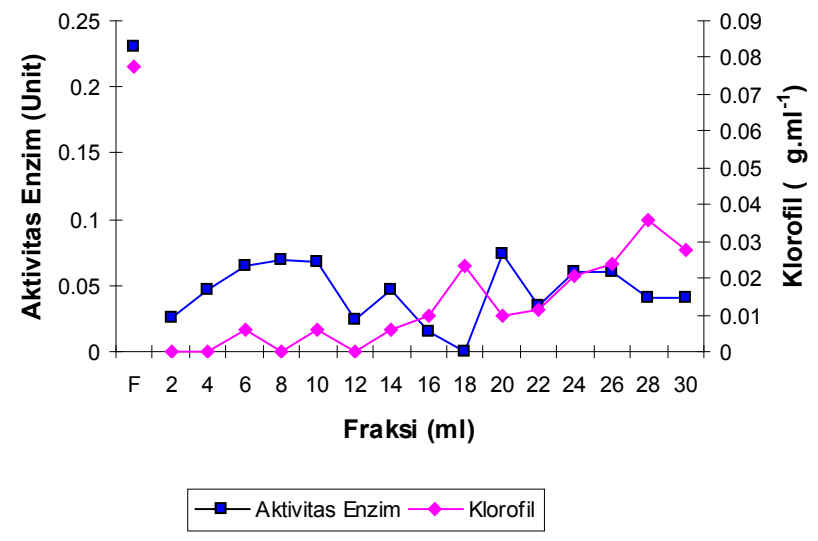

Gambar 2. Profil perubahan kadar klorofil dan aktivitas enzim eluen dari ekstrak tanaman biduri

Gambar 2 menunjukkan bahwa terjadi penurunan kadar klorofil yang sangat tajam selama elusi melalui kolom celite dibanding filtrat awal (F) yang belum dielusi, bahkan terdapat beberapa fraksi yang sudah tidak menunjukkan adanya klorofil. Akan tetapi eluen dengan minimal klorofil didapat sampai fraksi tabung $2 \mathrm{ml}$ ke-8 (fraksi $16 \mathrm{ml}$ ), selanjutnya menunjukkan adanya kenaikan klorofil yang cukup signifikan walaupun demikian kenaikan kadar klorofil sampai fraksi tabung $2 \mathrm{ml}$ ke-15 masih jauh lebih rendah daripada filtrat yang belum dielusikan. Seiring dengan penurunan kadar klorofil, nampaknya juga diikuti dengan penurunan aktivitas enzim. Namun demikian fraksi dengan minimal klorofil juga menunjukkan adanya aktivitas protease yang cukup tinggi.
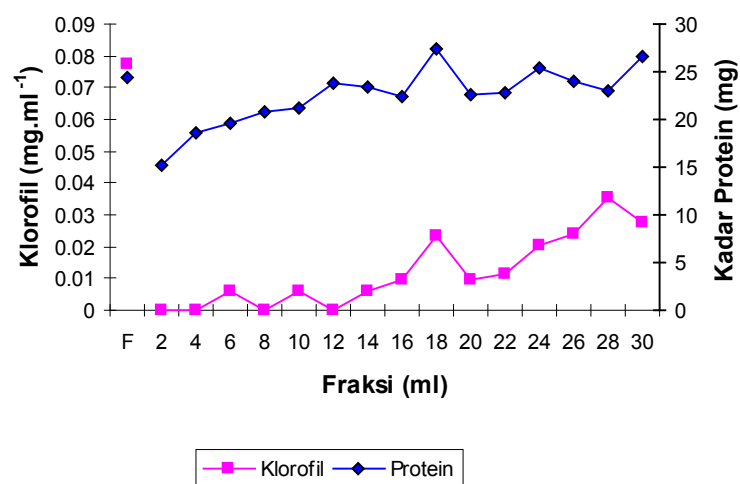

Gambar 3. Profil perubahan kadar klorofil dan kadar protein eluen dari ekstrak tanaman biduri

Gambar 3 menunjukkan bahwa seiring dengan penurunan kadar klorofil sampai fraksi tabung $2 \mathrm{ml}$ ke-8 (fraksi $16 \mathrm{ml}$ ) ternyata juga diikuti dengan penurunan kadar protein terlarut eluen dari ekstrak tanaman biduri yang sangat signifikan. Peningkatan kadar klorofil setelah fraksi $16 \mathrm{ml}$ juga menunjukkan peningkatan kadar protein eluen dari ekstrak tanaman biduri. Fraksi tabung $2 \mathrm{ml} \mathrm{ke-1}$ sampai ke-8 dengan minimal klorofil dan minimal protein (Gambar 2 dan Gambar 3) ternyata didapat aktivitas enzim yang tersebar pada semua fraksi. Hal ini berarti selama elusi selain terjadi penurunan klorofil juga terjadi penurunan protein non-enzim yang cukup baik. Untuk itu akhir elusi ditentukan pada fraksi tabung $2 \mathrm{ml} \mathrm{ke-} 8$ atau pada $16 \mathrm{ml}$ eluen. Selanjutnya dapat ditentukan volume loading sebesar 3,2 ml filtrat per gram celite atau sebesar 1.067 gram biduri setiap gram celite, dengan kapasitas loading absorban celite dalam menurunkan konsentrasi klorofil ekstrak tanaman biduri adalah sebesar $0,015 \mu \mathrm{g}$ klorofil/gram celite.

\section{Profil elusi protease tanaman biduri terdeklorofilasi pada celite absorbance pasca- freezing}

Profil elusi protease dari ekstrak tanaman biduri terdeklorofilasi pada absorban celite pasca-freezing tertera pada Gambar 4 dan Gambar 5. 


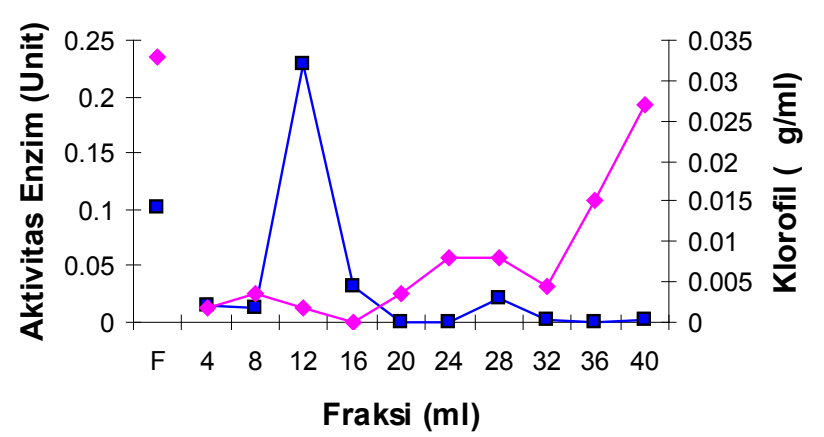

$\longrightarrow$ Aktivitas Enzim Total $\multimap$ Klorofil

Gambar 4. Profil perubahan kadar klorofil dan aktivitas enzim eluen dari ekstrak tanaman biduri pasca-freezing

Gambar 4 menunjukkan bahwa terjadi penurunan kadar klorofil yang sangat tajam selama elusi melalui kolom kromatografi dengan absorban celite dibanding filtrat awal (F) yang belum dielusi, bahkan terdapat fraksi yang sudah tidak menunjukkan adanya klorofil (fraksi $16 \mathrm{ml}$ ). Akan tetapi eluen dengan minimal klorofil didapat sampai fraksi tabung $4 \mathrm{ml}$ ke-8 (fraksi $32 \mathrm{ml}$ ), selanjutnya menunjukkan adanya kenaikan klorofil yang sangat signifikan. Seiring dengan penurunan kadar klorofil, nampaknya juga diikuti dengan penurunan aktivitas enzim. Namun demikian fraksi dengan minimal klorofil masih menunjukkan adanya aktivitas protease. Gambar 4 juga menunjukkan bahwa protein enzim paling banyak terelusi pada fraksi-fraksi awal terutama pada fraksi $12 \mathrm{ml}$ yang kadar klorofilnya juga relatif rendah.

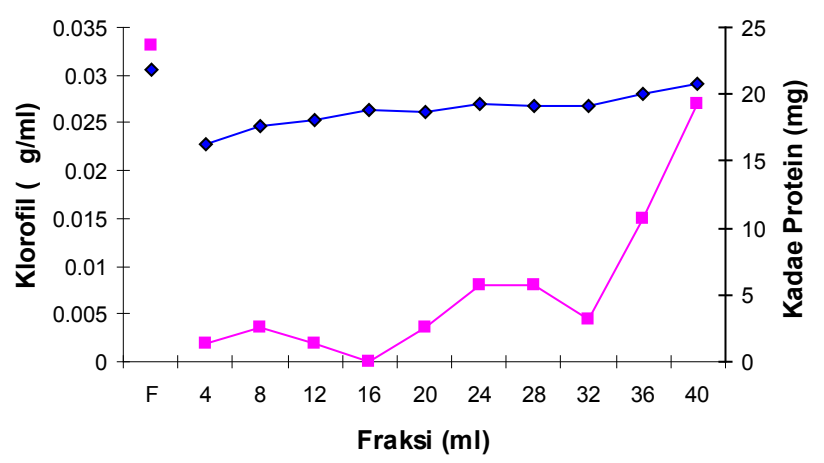

$\neg-$ Klorofil $\multimap$ Kadar Protein

Gambar 5. Profil perubahan kadar klorofil dan kadar protein eluen protease dari ekstrak tanaman biduri pasca-freezing

Gambar 5 menunjukkan bahwa seiring dengan penurunan kadar klorofil sampai fraksi $32 \mathrm{ml}$ ternyata kadar protein terlarut eluen dari ekstrak tumbuhan biduri pasca- freezing juga relatif rendah. Peningkatan kadar klorofil di atas fraksi $32 \mathrm{ml}$, juga menunjukkan peningkatan kadar protein eluen dari ekstrak tanaman biduri pasca-freezing. Fraksi tabung $4 \mathrm{ml}$ ke- 1 sampai ke- 8 dengan minimal klorofil dan minimal protein (Gambar 4 dan Gambar 5) ternyata didapat aktivitas enzim yang relatif lebih tinggi daripada fraksi-fraksi akhir. Untuk itu akhir elusi ditentukan pada fraksi tabung $4 \mathrm{ml}$ ke- 8 atau pada $32 \mathrm{ml}$ eluen. Dalam hal ini volume loading sebesar 6,4 $\mathrm{ml}$ filtrat setiap gram celite atau 2,13 gram biduri setiap gram celite, dengan kapasitas loading absorban celite dalam menurunkan konsentrasi klorofil ekstrak tanaman biduri pasca-freezing adalah sebesar $0,004 \mu \mathrm{g}$ klorofil/gram celite.

Gambar 6 merupakan perbandingan perubahan klorofil, protein maupun aktivitas enzim protease dari tanaman biduri pada elusi pertama (pra-freezing) dengan elusi kedua (pasca-freezing).

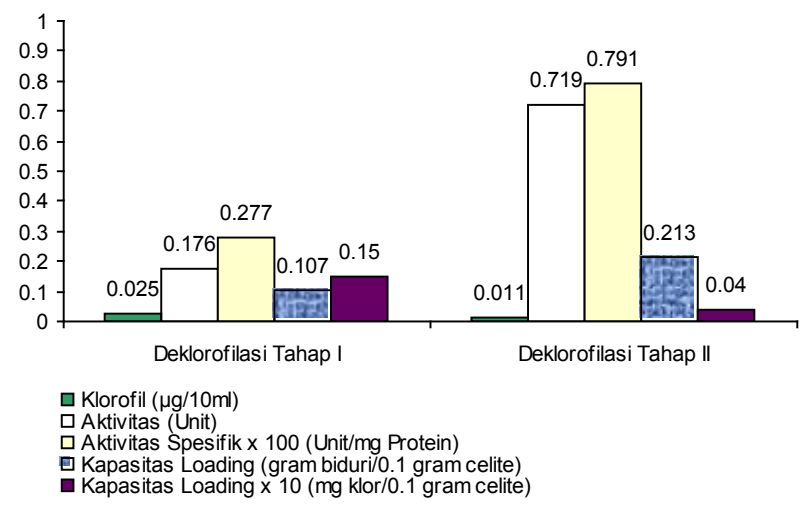

Gambar 6. Histogram perbandingan profil eluen protease dari ekstrak tanaman biduri terdeklorofilasi pra-freezing dan pascafreezing

Gambar 6 menunjukkan bahwa hasil elusi tahap pertama didapat eluen terdeklorofilasi sebanyak $16 \mathrm{ml}$ atau kapasitas loading-nya sebesar 1,07 gram biduri per gram celite. Akan tetapi setelah ekstrak tanaman biduri dibekukan selama 12 jam didapat eluen biduri terdeklorofilasi yang lebih banyak yakni sebesar $32 \mathrm{ml}$ dengan volume loading sebesar 2,13 gram biduri per gram celite. Sehingga terjadi peningkatan sebesar 2 kali volume cara deklorofilasi tahap pertama, yakni terjadi penurunan kadar klorofil menjadi di bawah 44\% kadar klorofil crude protease biduri elusi tahap pertama. Terlebih bila dibandingkan dengan kadar klorofil filtrat awal sebelum dideklorofilasi, terjadi penurunan sampai di bawah 1,5\%-nya, bahkan terjadi peningkatan aktivitas spesifik sebesar $286 \%$ dibanding cara deklorofilasi tahap pertama. Akan tetapi Gambar 6 menunjukkan bahwa kapasitas loading celite dalam menjerap klorofil terjadi penurunan dari $0,015 \mu \mathrm{g}$ klorofil/gram celite (pada elusi 
tahap pertama) menjadi sebesar $0,004 \mu \mathrm{g}$ klorofil/gram celite (pada elusi tahap kedua).

\section{PEMBAHASAN}

Elusi melalui kolom dengan absorban celite sampai fraksi $16 \mathrm{ml}$ filtrat (deklorofilasi tahap 1), dihasilkan crude protease biduri dengan minimal klorofil. Seiring dengan penurunan klorofil juga terjadi penurunan kadar protein. Hal ini karena celite bersifat menjerap klorofil dan molekul protein serta klorofil yang terikat dengan molekul protein. Sebagaimana dilaporkan oleh Jumpatong et al. (2006) bahwa dalam proses isolasi komponen produk alam dari tanaman berupa matriks organik yang tersusun atas karbohidrat, tanin, pigmen dan lain-lain yang umumnya harus dihilangkan dari crude ekstrak. Witono dkk. (2006) menambahkan, bahwa enzim protease yang diekstrak secara langsung dari bagian tanaman (daun dan pucuk batang) biduri masih mengandung pigmen klorofil yang terikat bersama protein enzim. Menurut Sharpe (2005) celite berperan sebagai filtrasi yang mampu menghilangkan protein dan berbagai impuritas termasuk klorofil dari suatu produk organik.

Elusi setelah fraksi $16 \mathrm{ml}$ filtrat (deklorofilasi tahap 1) terjadi peningkatan klorofil yang cukup signifikan. Hal ini menunjukkan bahwa celite memiliki kapasitas loading tertentu dalam menjerap klorofil, yakni sebesar $0,015 \mu \mathrm{g}$ klorofil/gram celite. Seiring dengan peningkatan kadar klorofil, juga diikuti dengan peningkatan kadar protein pada elusi setelah fraksi $16 \mathrm{ml}$ filtrat.

Dibandingkan dengan deklorofilasi tahap 1, filtrat tanaman biduri yang dibekukan selama 12 jam (deklorofilasi tahap 2) didapat eluen biduri terdeklorofilasi yang lebih banyak, yakni sebesar $32 \mathrm{ml}$ atau terjadi peningkatan sebesar 2 kali volume cara tahap pertama, dengan penurunan kadar klorofil menjadi di bawah 44\% kadar klorofil crude protease biduri elusi tahap pertama (pra-freezing), bahkan terjadi peningkatan aktivitas spesifik sebesar $86 \%$ dibanding cara tahap pertama. Hal ini diduga selama pembekuan selain terjadi penurunan klorofil, juga terjadi presipitasi protein non-enzim yang lebih besar dan perlakuan tersebut tidak menyebabkan penurunan aktivitas proteolitik dari enzim biduri. Terbukti dengan aktivitas spesifik protease yang paling tinggi pada fraksi-fraksi awal (gambar tidak ditunjukkan). Sehingga treatment freezing dan elusi dalam absorban celite sangat memungkinkan untuk dijadikan sebagai salah satu alternatif proses purifikasi suatu crude protease dari ekstrak tanaman.

Walaupun demikian, perlakuan freezing selain mempresipitasi protein non enzim juga klorofil yang terikat (bounding) dengan protein non enzim, namun sangat sulit menurunkan klorofil yang terikat dengan protein enzim atau karena diduga terdapat klorofil yang terikat secara kuat dengan protein enzim sehingga masih sulit dijerap secara keseluruhan oleh celite. Sebagaimana dibuktikan dengan menurunnya kapasitas loading celite dalam menjerap klorofil dari $0,015 \mu \mathrm{g}$ klorofil/gram celite (pada elusi tahap pertama) menjadi sebesar $0,004 \mu \mathrm{g}$ klorofil/gram celite (pada elusi tahap kedua).

Selanjutnya dapat direkomendasikan, bahwa untuk memproduksi enzim protease yang diekstrak secara langsung dari tanaman biduri dapat dilakukan dengan teknik deklorofilasi, yakni elusi filtrat melalui kolom dengan celite absorbance pascapembekuan preparat. Deklorofilasi melalui celite absorbance lebih baik bila dibandingkan dengan menggunakan arang aktif dan lebih murah bila dibanding menggunakan resin sephadex, bahkan diduga lebih mudah dibanding menggunakan teknik elektrokoagolasi dan lebih aman dibanding menggunakan pelarut kimia. Selanjutnya perlu ditelaah aplikasi protease terdeklorofilasi pada proses pangan yang sesuai.

\section{KEPUSTAKAAN}

Gilpin L, 2001. Methods for Analysis of Benthic Photosynthetic pigment, School of Life Sciences, Napier University, Edinburg, 1-3.

Jumpatong K, Phutdhawong W, dan Buddhasukh D, 2006. Dechlorophyllation by Electrocoagulation. Molecules. 11: 156-162.

Rao MB, Tanksale AM, Ghatge MS dan Desphande VV, 1998. Molecular and Biotechnological Aspects of Microbial Protease, American Society for Microbiology, 62(3): 597-607.

Sharpe AN, 2005. Membrane Filtration and Useful info Re spreadfilters and Replicators. Filtaflex, Ontario, 1-5.

Stoknes I dan Rustad T, 1995. Proteolytic Activity in Muscle from Atlantic salmon (Salmo salar), J. Food Sci., 60(4): 711-714.

Suhartono MT, Lestariono LN, dan Tanoyo T, 1995. Study on Protease from Aspergillus oryzae Isolated from Soy Sauce Processing in Indonesia. J. Indonesia Trop. Agric., 6 (2): 21-25.

Suryabrata S, 1994. Metodologi Penelitian. Raja Grafindo Persada, Jakarta, 9-57.

Van Stenis, 1992. Flora. Pradnya Paramita, Jakarta, 255-326.

Walker JM, 2002. The Protein Protocols Handbook. Second Edtion. Humana Press, New Jersey, 3-10.

Witono Y, 2002a. Isolasi dan Karakterisasi Enzim Protease dari Getah Tanaman Biduri. J. Teknologi Hasil Pertanian, 1(1): 1-14.

Witono Y, 2002b. Pemanfaatan Enzim Protease dari Tanaman Biduri untuk Pengolahan Makanan. J. Sains dan Teknologi, 1(1): 32-37. 
Witono Y, Subagio A, Susanto T dan Widjanarko SB, 2006. Telaah Teknik Produksi Enzim Protease dari Tanaman Biduri (Calotropis gigantea), Prosiding Seminar Nasional Perhimpunan Ahli Teknologi Pangan Indonesia, Yogyakarta.
Word OP, 1983. Properties of Microbial Protease. In Microbial Enzyme and Biotechnology. (Ed Forgety). Appl. Publ. London, 56-102.

Reviewer: Dr. Afaf Baktir, M.Si., Apt. 